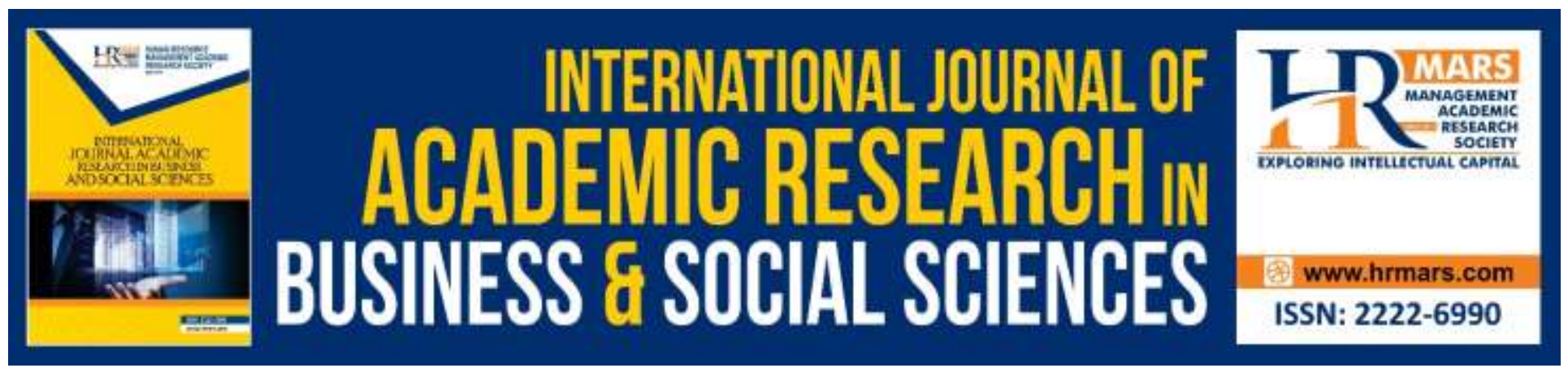

\title{
Service Quality among Sports and Fitness Practitioners in Malaysia: A Case Study
}

\section{Wan Ahmad Munsif Wan Pa, Norlena Salamuddin, Noraziah Mohd Zin \& Abu Yazid Abu Bakar}

To Link this Article: http://dx.doi.org/10.6007/IJARBSS/v9-i7/6115

DOI: $10.6007 /$ IJARBSS/v9-i7/6115

Received: 23 May 2019, Revised: 15 June 2019, Accepted: 01 July 2019

Published Online: 26 July 2019

In-Text Citation: (Pa, Salamuddin, Zin, \& Bakar, 2019)

To Cite this Article: Pa, W. A. M. W., Salamuddin, N., Zin, N. M., \& Bakar, A. Y. A. (2019). Service Quality among Sports and Fitness Practitioners in Malaysia: A Case Study. International Journal of Academic Research in Business and Social Sciences, 9(7), 273-284.

Copyright: (C) 2019 The Author(s)

Published by Human Resource Management Academic Research Society (www.hrmars.com)

This article is published under the Creative Commons Attribution (CC BY 4.0) license. Anyone may reproduce, distribute, translate and create derivative works of this article (for both commercial and non-commercial purposes), subject to full attribution to the original publication and authors. The full terms of this license may be seen

at: http://creativecommons.org/licences/by/4.0/legalcode

Vol. 9, No. 7, 2019, Pg. 273 - 284

http://hrmars.com/index.php/pages/detail/IJARBSS

JOURNAL HOMEPAGE

Full Terms \& Conditions of access and use can be found at http://hrmars.com/index.php/pages/detail/publication-ethics 


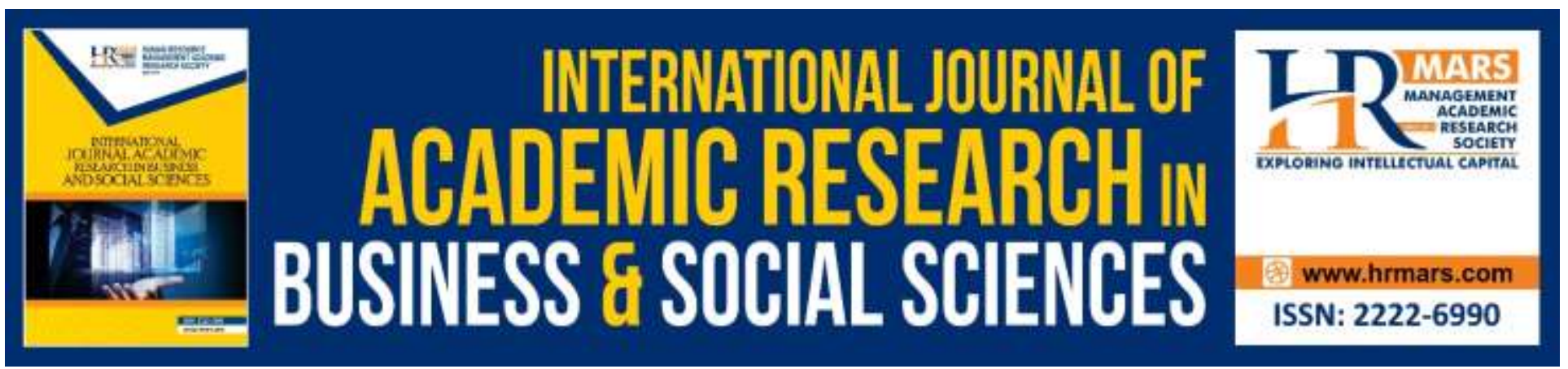

\title{
Service Quality among Sports and Fitness Practitioners in Malaysia: A Case Study
}

\author{
Wan Ahmad Munsif Wan $\mathrm{Pa}^{1}$, Norlena Salamuddin ${ }^{1}$, Noraziah Mohd \\ Zin $^{2} \&$ Abu Yazid Abu Bakar ${ }^{1}$ \\ ${ }^{1}$ Faculty of Education, Universiti Kebangsaan Malaysia, 43600 UKM Bangi, Selangor, MALAYSIA \\ ${ }^{2}$ Faculty of Health Sciences, Universiti Kebangsaan Malaysia, 50300 Kuala Lumpur, MALAYSIA
}

\section{Abstract}

The establishment of a fitness center is a matter of stress and serious risk to every manager and fitness trainer. To encourage participation in physical activity, firstly, it is vital to educate the manager and fitness trainer to perform their highest quality of services. Sports and recreation programs from any education institution should be able to groom their student on how to deliver the knowledge and perform the best quality of services to the people. Generally, the measurement of service quality to the fitness industry in Malaysia is still bland. The quality of an organization's service reflects the extent to which the customer's needs and satisfaction can be met. In addition, the incidence of illness among people today is associated with unhealthy lifestyle such as lack of exercise, smoking, eating disorders and drug abuse. This may be due to lack of emphasis on psychosocial aspects and health promotion. In this regard, the study aims to measure the quality of services in selected fitness centers in the state of Perlis. This study will serve as useful information to fitness center managers based on the satisfaction of the gym users, especially in terms of health and fitness. The fitness centers are Fitness @ Ku, Rock Fitness, Amzex Fitness and Unicity Fitness in Perlis, the most northern state of Peninsular Malaysia. A total of 280 respondents were randomly selected from the target group. The instrument used in this study was SERVQUAL which has five components. The data was inferentially analyzed (independent t-test and One-Way ANOVA) using the Statistical Package for Social Sciences (SPSS) software version 22.0. Based on gender and family income of the respondents, the study found significant result on service quality of the participated fitness centers.

Keywords: Case Study, Fitness, Service Quality, Sports, Malaysia.

\section{Introduction}

The fitness industry has grown rapidly around the world. It is a competitive industry and there is an increase in customer power and managers should focus on consumers (Afthinos, Theodorakis \& Nassis, 2005). To encourage participation in physical activity, firstly, it is vital to educate the manager and fitness trainer to perform their highest quality of services. This need to be start from the grass 
root stages, such from the high education institution or school. Sports and recreation programs from any education institution should be able to groom their student on how to deliver the knowledge and perform the best quality of services to the people. Due to the focus on community recreation and wellbeing, many fitness centers have been opened around the state of Perlis. There is a old and newly opened fitness center but fails to provide user requirements or fail to showcase good service quality. To encourage more members of the fitness center, managers should provide high-tech equipment as well as good coaches/employees in order to meet the physical fitness activities or desired exercise activities. The quality of service to consumers is important in the fitness center around the state of Perlis as this can help improve consumer satisfaction while increasing profits to their organization.

Haliyana and Atiah (2014) stated that the level of customer satisfaction with the service quality of an organization can be judged from the problems and views that the customers are often asked about a given service. This level of satisfaction is a measure of the quality of services whether positive or negative. Through these measurements, improvements such as improving the quality of service and the smooth running of an organization's operations can be provided to customers or users. In line with the problems often associated with the quality of service and subsequently increased the implementation of physical fitness activities. The study will be conducted around selected fitness centers in the state of Perlis which serves as a place to enhance the physical fitness level.

According to Zeithaml, Bitner and Gremler (2006), if the organization does not carry out marketing research specifically to the wishes of customers, this may lead to failure in providing customer needs. Despite the extensive review of service quality in various sectors, there has been no significant study of the impact of quality of service on the health and fitness center especially in Perlis. Gymnasium members around the fitness center in Perlis state are increasingly concerned with consumer rights and making comparisons of acceptable services and services that have been received.

Among the methods used to measure service quality are to take into consideration customer expectations of the services provided and their experience with services obtained (Robinson, 1999). Records show the quality of service quality measurement used by the researchers is the SERVQUAL Model presented by Parasuraman, Zeithaml and Berry (1985). Usually SERVQUAL is used as an approach to measure the quality of services through a comparison of customer experience to services obtained with customer expectations of services provided. In short, this model explains that the level of service quality can be measured through the differences between the experience score and the customer's expected score on the service. The higher the positive score obtained shows the better the quality of a service, the greater the negative score obtained indicates the lower the quality of the service.

Every month or even year, the fitness center organization sets the target client to come to work out. This goal setting aims to increase the arrival of users who are major contributors to the economy. However, what is the quality of the fitness centers around the state of Perlis being at its best? In order to achieve a strong user satisfaction aspect, the management should identify the quality of service first. This problem generates the researcher's idea to conduct research on the quality of service that is aimed at the user's desire to return to the fitness center around the state of Perlis. 
INTERNATIONAL JOURNAL OF ACADEMIC RESEARCH IN BUSINESS AND SOCIAL SCIENCES

Vol. 9, No. 7, July, 2019, E-ISSN: 2222-6990 @ 2019 HRMARS

\section{Research Backgrounds}

\section{Service Quality Model}

Existence is a physical aspect of service. According to Zeithaml, Bitner and Gremler (2006), define the existence of physical facilities, equipment, personnel and communication materials. Availability provides physical aspect or presentation of services where users will make an assessment. Normally existence is the first impression that is the impression that will have a lasting effect. Generally, all fitness centers in Perlis state elected in this study should be proud of having the latest physical facilities and are suitable for use by both male and female users. All selected fitness centers also provide personal trainers. According to Kim and Kim (1995) and Dhurup, Singh and Surujlal (2006), the existence of facilities or equipment such as treadmills, encumbrances and existence also refers to the performance of staff at the fitness center. Colleen (2009) found that there is no significant difference between gender and existence.

Trustworthiness is the ability to fulfill the promise that has been conveyed to the customer. According to Zeithaml, Bitner and Gremler (2006), trustworthiness is the ability to enforce the service that has been promised. They also stated reliability as the most important thing to the perception of quality of service among customers in the United States. According to Kim and Kim (1995) and Dhurup, Singh and Surujlal (2006), trustworthiness is the ability of employees to perform services that have been promised perfectly in the fitness center. The extent, to which the trustworthiness will be received by the user, depends on the staff itself. In order to increase the positive perception of consumers to believe in the services they will receive, the selected fitness center in Perlis also delivers credibility through promotions in social media such as Facebook and Instagram. Colleen (2009) found that there is no significant difference between gender and trustworthiness factor.

Responsive is a response and the ability to help customers. According to Zeithaml, Bitner and Gremler (2006), responsiveness is the will of the employee to help the customer to get good service. This dimension emphasizes the attention and timeliness of dealing with customers in terms of questions, complaints and issues. They advise that service providers who are supposed to be active and voluntary in assisting their customers and immediately providing services. This dimension suggests that service providers need to be more tolerant in solving their client's problems and requests. Organizations should also have the ability to customize services to deal with their customers.

Guarantee is an injection of confidence and trust given to the customer. According to Zeithaml, Bitner and Gremler (2006), guarantees are the knowledge and discretion owned by the workers as well as the organizational ability to channel confidence and trust to customers. According to Kim and Kim (1995) and Dhurup, Singh and Surujlal (2006), guarantees the discretionary aspects, credibility and competence of workers at the fitness center. According to Yeo (2008), the evaluation of service quality depends on how the actual performance is compared to expectations.

Empathy is a service to the customer as an individual. According to Zeithaml, Bitner and Gremler (2006), empathy is the attitude of care and attention given individually by organizational workers to customers. The empathy aspect brings the message to customers that they are special to the organization. Kim and Kim (1995) and Dhurup, Singh and Surujlal (2006), indicate that empathy have links to individual care and attention given by the fitness center staff to their customers. 
INTERNATIONAL JOURNAL OF ACADEMIC RESEARCH IN BUSINESS AND SOCIAL SCIENCES Vol. 9, No. 7, July, 2019, E-ISSN: 2222-6990 @ 2019 HRMARS

\section{Service Theory}

Armstrong and Kottler (2006) proposes that service, is theoretically founded by four main components as illustrated in Figure 1.

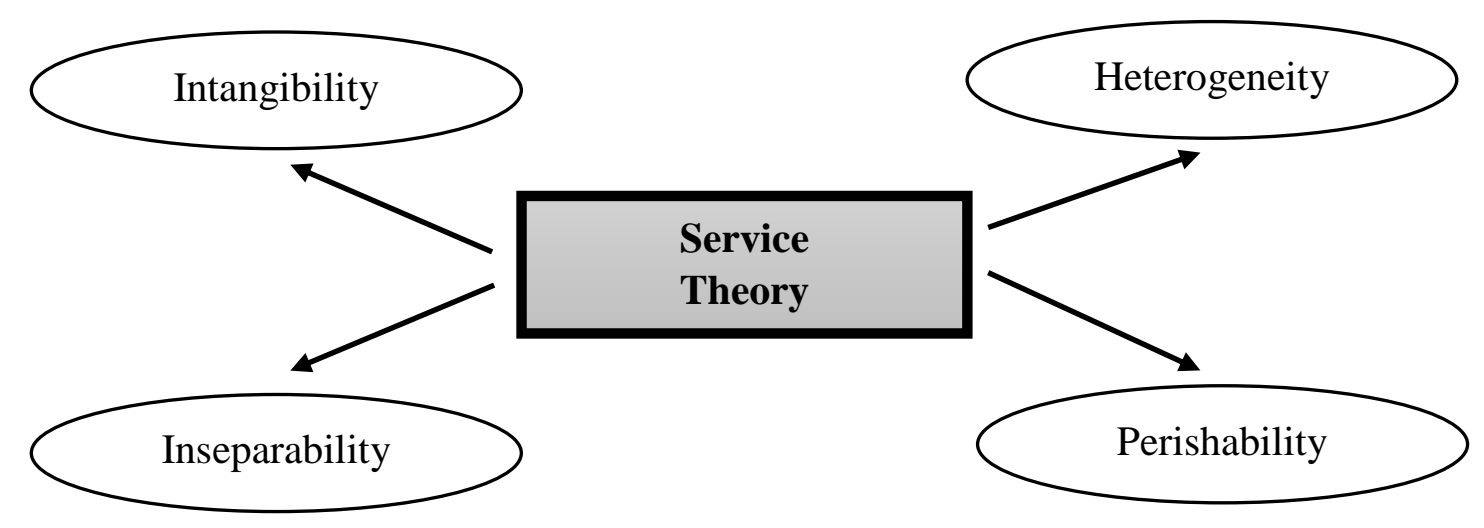

Figure 1: Service Theory by Armstrong and Kotler (2006)

The intangible aspect is the key feature that distinguishes the service from the product (Mackay \& Crompton, 1988). The service is considered intangible in the sense that they cannot be viewed in a rough, sensual, sensual, or touch-like manner (Kandampully, 2002). In fact, the service is not physically visible. This makes it difficult for users to inspect or identify quality before purchasing or using the service. Challenges to marketers are in terms of persuading consumers with the services offered.

According to Lovelock and Gummeson (2004) heterogeneity is referred to as a challenge to explain the existence of standards when behavior and performance vary, not only among service workers, but also when users have unique requests and service experiences in a unique way. Services are diversity depending on who, when, where, and how the service provider does. This distinction exists because of various things including interaction between service providers and their customers, environmental conditions, and others. Marketers need to ensure uniformity of services offered such as employee training and continuous improvement to ensure the quality of services offered.

The service is non-durable in the sense that they cannot be stored, stored for reuse in the future, resold, or returned in the same sense as the product (Lovelock \& Gummesson, 2004). This means that services cannot be inventoried. The service can only be offered when it is needed, and served by the service provider as soon as it is required by the customer. The demand and service aspect of this service should be emphasized by marketers to ensure service is available when needed.

Production, distribution, and use of services in a service meeting are simultaneous processes (Svensson, 2003). The service to be offered to the user is inseparable from the party who will provide the service. This means that services cannot be created with only one party (in other words, supply and use of services need to be done simultaneously). Marketers must ensure that demand and service offerings are well managed. 
INTERNATIONAL JOURNAL OF ACADEMIC RESEARCH IN BUSINESS AND SOCIAL SCIENCES

Vol. 9, No. 7, July, 2019, E-ISSN: 2222-6990 @ 2019 HRMARS

\section{Methodology}

The design of this study is quantitative study using survey method. The survey method is suitable for this study because the questionnaire can be given to the respondents as possible (Robert, Spink \& Pemberton, 1999) to obtain information about the quality of services around the fitness center in Perlis state based on gender differences and family monthly income. The sampling method used by the researcher is simple random sampling (randomized in the target group). This is because researchers are focusing on individuals or users who come to the selected fitness center. The sampling size was 280 both men and women. Table 1 displays the number of respondents according to the selected fitness centers.

Table 1: Number of Respondents for Each Fitness Center

\begin{tabular}{|c|c|}
\hline Name of Fitness Center & Number of Respondents \\
\hline Fitness@ Ku & 70 \\
\hline Rock Fitness & 70 \\
\hline Amzex Fitness & 70 \\
\hline Unicity Fitness & 70 \\
\hline Total & 280 \\
\hline
\end{tabular}

The instrument for this study is SERVQUAL which has five components, adapted from the study of Colleen Lotz conducted in 2009. The constructs are existence (4 items), trustworthiness (4 items), responsiveness ( 4 items), assurance ( 4 items), and empathy ( 5 items). Table 2 shows the specification of measurements and data analyzing procedures. 
INTERNATIONAL JOURNAL OF ACADEMIC RESEARCH IN BUSINESS AND SOCIAL SCIENCES Vol. 9, No. 7, July, 2019, E-ISSN: 2222-6990 @ 2019 HRMARS

Table 2: Specification of measurements and data analyzing procedures

\begin{tabular}{|c|c|c|c|}
\hline Part & $\begin{array}{c}\text { Details of } \\
\text { Measurement }\end{array}$ & Number of Items & Analysis \\
\hline$A$ & Demography & $\begin{array}{c}11 \\
\text { (Item A1-A11) } \\
\end{array}$ & Descriptive Statistic \\
\hline \multirow[t]{5}{*}{$B$} & Service Quality & $\begin{array}{c}\text { Existence } \\
\text { (Item B1-B4) }\end{array}$ & Inferential statistic \\
\hline & & $\begin{array}{l}\text { Trustworthiness } \\
\text { (Item B5-B8) }\end{array}$ & $\begin{array}{c}\text { Independent T-Test } \\
\text { One Way ANOVA } \\
\text { Test }\end{array}$ \\
\hline & & $\begin{array}{l}\text { Responsive } \\
\text { (Item B9-B12) }\end{array}$ & \\
\hline & & $\begin{array}{c}\text { Guarantee } \\
\text { (Item B13-B16) }\end{array}$ & \\
\hline & & $\begin{array}{c}\text { Empathy } \\
\text { (Item B17-B21) }\end{array}$ & \\
\hline
\end{tabular}

Pilot study was conducted at the fitness center of UITM Perlis. A total of 50 respondents were involved in this pilot study. The Cronbach's Alpha value derived for this service quality (SERVQUAL) instrument was .814. All items were accepted, as the value of all items in the component matrix was higher than 0.6 .

Before the questionnaire will be distributed to the respondents, the researchers will first submit a questionnaire to two experts in the field of language for their validation and validity as the researchers have translated the questionnaire to Bahasa Malaysia through 'back to back translation' (Brislin, Lonner \& Thorndike, 1973). In addition, researchers are required to obtain permission to conduct studies at the fitness center identified through the official letter of authorization to conduct the study. Researchers have also sought permission from the management to get help from their employees to help distribute questionnaires. The questionnaire were distributed at selected fitness centers in the state of Perlis and only distributed to male and female client. Improper data collection will impact the outcome of the study and cause failure to describe the results. The questionnaires and pen are distributed to a large number of respondents and this saves time and expenditure of researchers. Researchers and assistants from the fitness center are waiting for the respondents to complete the questionnaire. The length of a respondent's response to complete the instrument is 10 minutes. 
INTERNATIONAL JOURNAL OF ACADEMIC RESEARCH IN BUSINESS AND SOCIAL SCIENCES

Vol. 9, No. 7, July, 2019, E-ISSN: 2222-6990 @ 2019 HRMARS

\section{Results and Discussion}

Result has shown that assurance was the major component of service quality that influence the satisfaction and desire of users to come to the fitness center as compared to other components (refer Table 3). This finding was different from research finding of Pairot (2008) which found that guarantee was a key component of service quality that affects consumer satisfaction. The result was also not aligned with findings of Colleen Lotz's research in 2009 which found that there were significant differences in all service quality components.

Table 3: Significant Component in Service Quality based on One-Way ANOVA Analysis

\begin{tabular}{llccccc}
\hline Service Quality & $\begin{array}{c}\text { Sum of } \\
\text { squares }\end{array}$ & df & Min of squares & F & Sig. \\
\hline Assurance & Between Group & 136.639 & 3 & 45.546 & 14.923 & .000 \\
& Within Group & 842.357 & 276 & 3.052 & & \\
& Total & 978.996 & 279 & & & \\
\hline
\end{tabular}

It is clear that the service theory proposed by Armstrong and Kotler in 2006 cannot be denied because the service is not physically visible. This makes it difficult for users to inspect or identify quality before buying or using the service. In this regard, each selected fitness center manager in Perlis should improve the quality of services, particularly the aspect of the guarantee. Workers in the fitness center need to cultivate self-confidence in members. The fitness center should provide children with safe playground facilities and offer simple membership fees. Workers in the fitness center need to have professional knowledge.

The findings show that there are significant differences in the components of existence, trustworthiness, assurance and empathy that influence individual satisfaction to come back to the fitness center based on gender. Overall, male users are more affected by these four components than female users. In contrast to the findings from Pairot (2008) where there is a significant difference to all components in service quality. Male users are more influenced by the components of reliability, assurance and empathy. Meanwhile, female users are more influenced by the components of existence and responsiveness. While the findings from Colleen Lotz (2009) study have shown that there are only significant differences in gender-responsive components. 
INTERNATIONAL JOURNAL OF ACADEMIC RESEARCH IN BUSINESS AND SOCIAL SCIENCES Vol. 9, No. 7, July, 2019, E-ISSN: 2222-6990 @ 2019 HRMARS

Table 4: Independent t-test analysis for the average difference in service quality between gender

\begin{tabular}{|c|c|c|c|c|c|c|c|}
\hline & Gender & $\mathbf{N}$ & Min & Std. Deviation & $\mathbf{t}$ & df & Sig. \\
\hline \multicolumn{2}{|c|}{ ExistenceMale } & 140 & 13.3857 & 1.76124 & \multirow[t]{2}{*}{2.640} & \multirow[t]{2}{*}{278} & \multirow[t]{2}{*}{0.009} \\
\hline & Female & 140 & 12.8357 & 1.72419 & & & \\
\hline \multicolumn{2}{|c|}{ Trustworthines Male } & 140 & 13.5000 & 1.89091 & \multirow[t]{2}{*}{1.987} & \multirow[t]{2}{*}{278} & \multirow[t]{2}{*}{0.048} \\
\hline $\mathrm{s}$ & Female & 140 & 13.0500 & 1.89784 & & & \\
\hline \multirow[t]{2}{*}{ Assurance } & Male & 140 & 12.8357 & 1.94385 & \multirow[t]{2}{*}{2.086} & \multirow[t]{2}{*}{278} & \multirow[t]{2}{*}{0.038} \\
\hline & Female & 140 & 12.3714 & 1.77652 & & & \\
\hline \multirow[t]{2}{*}{ Empathy } & Male & 140 & 16.8500 & 1.95240 & \multirow[t]{2}{*}{2.214} & \multirow[t]{2}{*}{278} & \multirow[t]{2}{*}{0.028} \\
\hline & Female & 140 & 16.3071 & 2.14542 & & & \\
\hline
\end{tabular}

The findings in Table 5 show trustworthiness, responsiveness, assurance and empathy as a component that affects the satisfaction and desires of consumers based on monthly income of between RM 1000 to RM 2000 and between RM 2000 to RM 3000 . There is a difference with the findings research conducted by Pairot (2008) the components of existence, reliability, responsiveness, and empathy for monthly income of 15000 Thai Baht and above RM 1770.00 and above. It is clear that users with monthly income between RM 1000 to RM 2000 and RM 2000 to RM 3000 are less concerned with the existence of components as they are more concerned with trustworthiness, responsive, assurance and empathy that can provide maximum satisfaction.

Table 5: Average difference in service quality score based on family income

\begin{tabular}{|c|c|c|c|c|c|}
\hline Variable & $\begin{array}{l}\text { (I) How much your } \\
\text { family monthly } \\
\text { income? }\end{array}$ & $\begin{array}{l}\text { (J) How much your } \\
\text { family monthly } \\
\text { income? }\end{array}$ & $\begin{array}{l}\text { Min } \\
\text { Differences } \\
(I-J)\end{array}$ & $\begin{array}{l}\text { Standard } \\
\text { Deviation }\end{array}$ & Sig. \\
\hline \multirow[t]{9}{*}{ Trustworthiness } & \multirow[t]{3}{*}{ RM 100 - RM 1000} & RM 1000 - RM 2000 & .78773 & .34121 & .099 \\
\hline & & RM $2000-$ RM 3000 & .07038 & .34733 & .997 \\
\hline & & RM 3000 and above & -.01881 & .35575 & 1.000 \\
\hline & \multirow{3}{*}{$\begin{array}{l}\text { RM } 1000-R M \\
2000\end{array}$} & RM 1000 - RM 2000 & -.78773 & .34121 & .099 \\
\hline & & RM 2000 - RM 3000 & -.71735 & .29411 & .072 \\
\hline & & RM 3000 and above & $-.80654^{*}$ & .30400 & .042 \\
\hline & \multirow{3}{*}{$\begin{array}{l}\text { RM } 2000-\text { RM } \\
3000\end{array}$} & RM 1000 - RM 2000 & -.07038 & .34733 & .997 \\
\hline & & RM 2000 - RM 3000 & .71735 & .29411 & .072 \\
\hline & & RM 3000 and above & -.08919 & .31087 & .992 \\
\hline
\end{tabular}


INTERNATIONAL JOURNAL OF ACADEMIC RESEARCH IN BUSINESS AND SOCIAL SCIENCES Vol. 9, No. 7, July, 2019, E-ISSN: 2222-6990 @ 2019 HRMARS

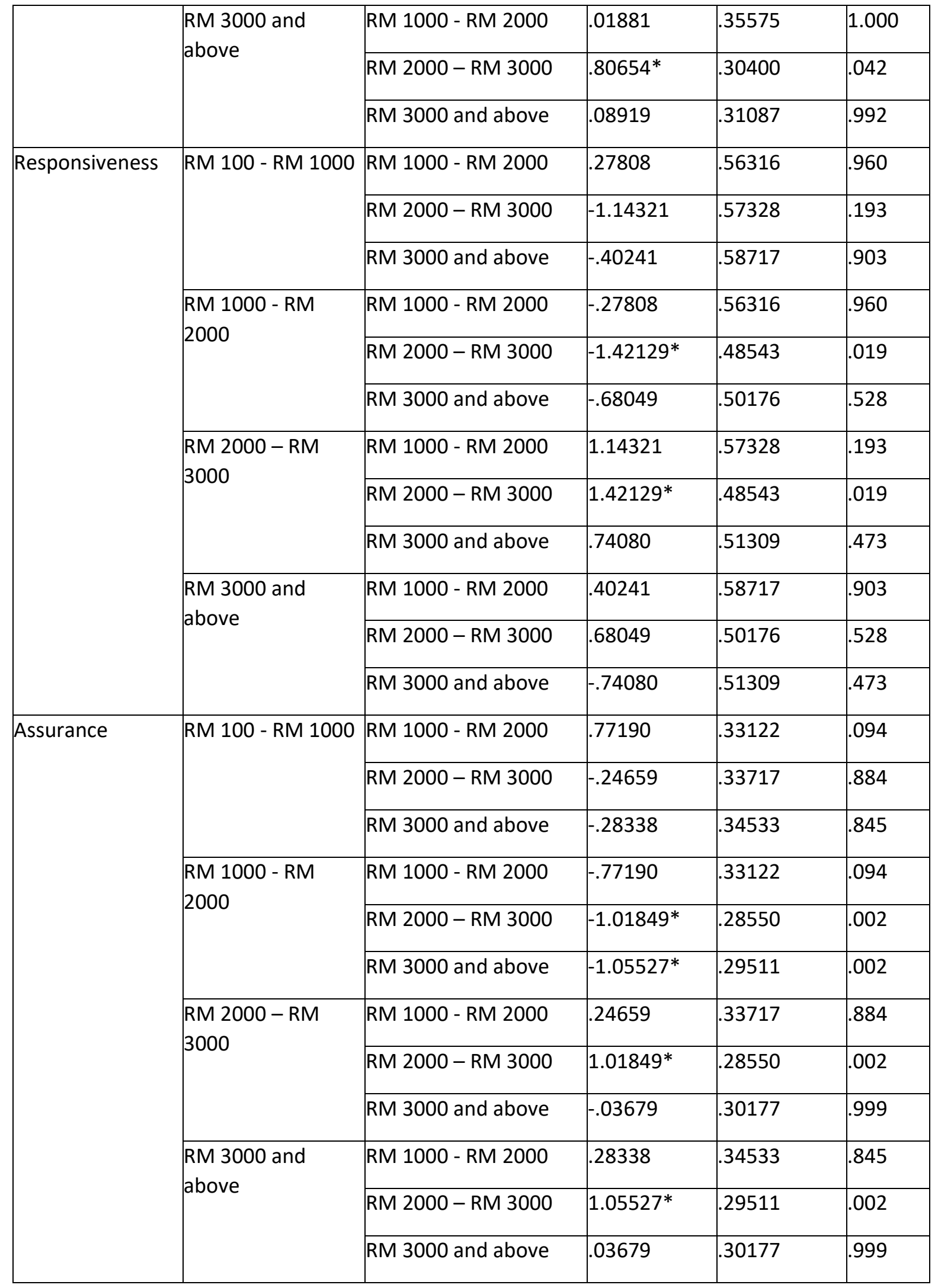


INTERNATIONAL JOURNAL OF ACADEMIC RESEARCH IN BUSINESS AND SOCIAL SCIENCES Vol. 9, No. 7, July, 2019, E-ISSN: 2222-6990 @ 2019 HRMARS

\begin{tabular}{|c|c|c|c|c|c|}
\hline \multirow[t]{12}{*}{ Empathy } & \multirow[t]{3}{*}{ RM 100 - RM 1000} & RM 1000 - RM 2000 & .68852 & .36762 & .242 \\
\hline & & RM $2000-$ RM 3000 & -.46890 & .37422 & .594 \\
\hline & & RM 3000 and above & .25964 & .38329 & .906 \\
\hline & \multirow{3}{*}{$\begin{array}{l}\text { RM } 1000-\text { RM } \\
2000\end{array}$} & RM 1000 - RM 2000 & -.68852 & .36762 & .242 \\
\hline & & RM $2000-$ RM 3000 & $-1.15742^{*}$ & .31688 & .002 \\
\hline & & RM 3000 and above & -.42888 & .32754 & .558 \\
\hline & \multirow{3}{*}{$\begin{array}{l}\text { RM } 2000-\mathrm{RM} \\
3000\end{array}$} & RM 1000 - RM 2000 & .46890 & .37422 & .594 \\
\hline & & RM 2000 - RM 3000 & $1.15742^{*}$ & .31688 & .002 \\
\hline & & RM 3000 and above & .72854 & .33493 & .133 \\
\hline & \multirow{3}{*}{$\begin{array}{l}\text { RM } 3000 \text { and } \\
\text { above }\end{array}$} & RM 1000 - RM 2000 & -.25964 & .38329 & .906 \\
\hline & & RM $2000-$ RM 3000 & .42888 & .32754 & .558 \\
\hline & & RM 3000 and above & -.72854 & .33493 & .133 \\
\hline
\end{tabular}

\section{Conclusion}

The purpose of this study is to examine how service quality affects respondents' satisfaction to come back to the fitness center. Quality of service is very important to the fitness center management to maintain the perception of consumers not to change to other fitness centers. This study has proven that it is not easy for consumers to maintain consumer loyalty to come to the same fitness center where there are obstacles such as facility factors; fitness equipment and amenities such as restrooms that are still in moderation, worker hospitality or fitness trainers who have less impact and promotion of less attractive membership fees. All in all, as consumers are always looking for quality in all kind of services, it is vital for the service providers to maintain and upgrade their service qualities in order to enhance the customers' satisfaction; hence, retain their supports for many years to come. In that sense, the sport and fitness practitioners are not excluded

\section{References}

Afthinos, Y., Theodorakis, N. D. Dan Nassis, P. (2005). Customers' expectations of service in Greek fitness centres. Managing Service Quality, 15(3): 245-258.

Armstrong, G. and Kotler, P. 2006. Marketing: An introduction. 8th Edition. New Jersey: PrenticeHall.

Brislin, R. W., Lonner, W. J. Dan Thorndike, R. M. (1973). Cross-Cultural Research Methods. New York: John Wiley \& Sons, CA: Sage Publications.

Lotz, C. (2009). Customer Service Quality at Selected Commercial Health and Fitness Centres in Kwazulu-Natal. Questionnaire for service quality in fitness centres. 
INTERNATIONAL JOURNAL OF ACADEMIC RESEARCH IN BUSINESS AND SOCIAL SCIENCES

Vol. 9, No. 7, July, 2019, E-ISSN: 2222-6990 ¿C 2019 HRMARS

Dhurup, M., Singh, P. C. \& Surujlal, J. (2006). Customer service quality at commercial health and fitness centres. South African Journal for Research in Sport, Physical Education and Recreation, 28(2): 39-54.

Tonot, H. \& Ibrahim, A. (2014). Penilaian Kualiti Perkhidmatan di One Stop Center (OSC) Kolej Universiti Islam Antarabangsa Selangor (KUIS).

Kandampully, J. (2002). Services management: The new paradigm in hospitality. Frenchs Forest. NSW: Pearson Education Australia.

Kim, D., Kim, S. Y. (1995). QUESC: An instrument for assessing the service quality of sport centers in Korea. J. Sport Manage, 9: 208-220.

Lovelock, C. \& Gummesson, E. (2004). Whither services marketing? In search of a new paradigm and fresh perspectives. Journal of Service Research, 7(1): 20-41.

MacKay \& Crompton, (1988). Definisi kualiti perkhidmatan. Marketing Quarterly, 9(4): 194-202.

Parasuraman, A., Zeithaml, V. A., \& Berry, L. L. (1985). A conceptual model of service quality and its implication for future research. Journal of Marketing, 49: 41-50.

Parasuraman, A., Zeithaml, V. A., \& Berry, L. L. (1988). SERVQUAL: A multiple-item scale for measuring consumer perceptions of service quality. Journal of Retailing, 64 (1): 12-40.

Robert, G. C., Spink, K. S., \& Pemberton, C. L. (1999). Learning Experiences in Sport Psychology. A practical guide to help students understand the major concepts in sport psychology. United States of America. Champaign, IL: Human Kinetics.

Robinson, S. (1990). Measuring service quality: current thinking and future requirements. Marketing Intelligence \& Planning, 58: 111-124.

Svensson, Lars, E. O. (2003). Escaping from a Liquidity Trap and Deflation: The Foolproof Way and Others, Journal of Economic Perspectives, 17(4): 145-166.

Zeithaml, V. A., Bitner, M. J. \& Gremler, D. D. (2006). Services Marketing: Intergrating Customer Focus across the Firm. 4th Edition. New York: McGraw-Hill. 